\title{
Ultrasonographic study of ovarian follicular dynamics in ewes during the oestrous cycle
}

\author{
J. P. Ravindra ${ }^{1}$, N. C. Rawlings ${ }^{{ }^{*}}$, A. C. O. Evans ${ }^{1}$ and \\ G. P. Adams ${ }^{2}$ \\ ${ }^{\mathrm{I}}$ Department of Veterinary Physiological Sciences; and ${ }^{2}$ Department of Veterinary Anatomy, \\ Western College of Veterinary Medicine, University of Saskatchewan, Saskatoon, Saskatchewan, \\ Canada S7N OWO
}

\begin{abstract}
Transrectal ovarian ultrasonography was performed daily in eight ewes during one interovulatory interval, using a $7.5 \mathrm{MHz}$, rigid, human prostate transducer, and a realtime B-mode scanner to record the numbers, diameters and position of all follicles $\geqslant 2 \mathrm{~mm}$ in diameter and the corpora lutea in both ovaries. Blood samples were taken once a day and were analysed for concentrations of $\mathrm{FSH}$, progesterone and oestradiol. During the interovulatory interval of $17.2 \pm 0.4$ days, antral follicles (follicles $>2 \mathrm{~mm}$ in diameter) emerged on all days except for days $1,5,15,16$ and 17. A significant increase in the numbers of follicles emerging was seen on days 2 and 11. The ovulatory follicle $(6.9 \pm 0.1 \mathrm{~mm}$ diameter) was retrospectively traced to emergence on day $11.1 \pm 0.3$ and grew over a period of $4.1 \pm 0.1$ days at a growth rate of $1.2 \pm 0.04 \mathrm{~mm}^{-1}{ }^{-1}$. The largest nonovulatory follicles of the same period grew at the same rate as ovulatory follicles and regressed over a period of $2.6 \pm 0.2$ days at a rate of $1.2 \pm 0.07 \mathrm{~mm} \mathrm{day}^{-1}$. The mean diameter of the largest follicles seen on each day of the oestrous cycle was lowest on the day of ovulation $(2.9 \pm 0.2 \mathrm{~mm})$, increased from day 3 to day $5(4.1 \pm 0.4 \mathrm{~mm})$ and again from day $I I$ to the day before ovulation $(6.9 \pm 0.1 \mathrm{~mm} ; P<0.05)$. The mean number of antral follicles $\geqslant 2 \mathrm{~mm}$ in diameter increased over the oestrous cycle from $4.5 \pm 0.4$ on day 3 to $7.2 \pm 0.7$ on day 11 and showed a sharp decline starting on day 15 , to a low of $3.5 \pm 0.3$ on the day of ovulation (day $17.2 \pm 0.4$ ). The corpus luteum could be identified by day 3 of the oestrous cycle in all the ewes, at a mean diameter of $11.5 \pm 0.3 \mathrm{~mm}$. The diameter increased to $13.3 \pm 0.6 \mathrm{~mm}$ on day 5 , and declined from day 11 to a diameter of $7.5 \pm 0.3 \mathrm{~mm}$ on the day of ovulation. Apart from increases before ovulation, there were no clear associations between serum concentrations of FSH or oestradiol and the pattern of follicular growth and regression. We concluded that follicle emergence appeared on many days of the oestrous cycle of ewes, with two phases of increased emergence. There was no discernible connection between follicle emergence and FSH secretion; the overall pattern of growth and regression of follicles was not as distinctly wave-like as in cattle. Follicular dominance was noted only just before ovulation, again, in contrast to cattle.
\end{abstract}

\section{Introduction}

The ovary of the ewe contains between 100 and 400 growing follicles, of which 10-40 are visible on the surface of the ovary (Cahill et al., 1979; McNatty et al., 1982). The control mechanisms that allow, in most breeds of sheep, only one of the developing follicles to complete growth and ovulate at the end of each oestrous cycle are not well understood. Gross and histological evaluation of ovaries of ewes killed at different stages of the oestrous cycle have led to contrasting conclusions. One study reported that two 'phases' of growth of

*Reprint requests.

Revised manuscript received 17 February 1994. follicles $\geqslant 2 \mathrm{~mm}$ in diameter occurred during an oestrous cycle (Brand and de Jong, 1973), whereas Hutchinson and Robertson (1966) concluded that the ovulatory follicle increased in size between $4 \mathrm{~h}$ and 5 days after the onset of the oestrous cycle and then remained constant in size until preovulatory enlargement. Serial laparotomy and ink labelling of large follicles at three different times during the oestrous cycle led to the conclusion that three or possibly more phases of follicular growth and atresia occurred during the oestrous cycle of ewes (Smeaton and Robertson, 1971). The presence of follicles sensitive to LH (Driancourt et al., 1988, 1990) and the growth of follicles to diameters of 4-6 mm (Webb and Gauld, 1985) have been documented during the luteal phase of the oestrous cycle in ewes. Day to day accounts of ovarian follicular 
changes have not been reported for individual ewes throughout the oestrous cycle, and the pattem of follicular development in ewes remains unclear. A detailed study of the pattern of growth and regression of large antral follicles throughout the oestrous cycle would give a basis to our understanding of the regulation of antral follicle dynamics in ewes.

The use of ultrasonography to monitor day to day ovarian follicular changes in cattle during an oestrous cycle have shown clear wave patterns of growth and regression of large antral follicles (Fortune et al, 1988; Pierson and Ginther, 1988; Savio et al., 1988; Sirois and Fortune, 1988; Knopf et al., 1989). Such studies have made it possible to begin to understand the processes of follicular recruitment, selection and dominance and the hormonal changes associated with these follicular events in cattle. There are no similar studies in sheep, principally owing to the lack of adaptation of techniques suitable for repeated, non-invasive monitoring of ovarian follicular events to this small ruminant. The purpose of the present study was to apply the transrectal ultrasonography used in cattle to the ewe, to monitor ovarian follicular events throughout the oestrous cycle. The aim was to describe the growth and regression of large antral follicles, and to relate ovarian changes to circulating concentrations of gonadotrophins and ovarian steroid hormones.

\section{Materials and Methods}

\section{Animals and experimental procedure}

Eight Western White-Faced, cross-bred, adult ewes were kept at pasture during the breeding season. The Western White Face is largely of Rambouillet and Columbia breeding and produces $1.5 \pm 2$ lambs per ewe (Rawlings et al., 1987) with a mature weight of $70 \mathrm{~kg}$. Oestrous detection was done with three vasectomized rams fitted with colour-marking harnesses. Ovarian follicular activity was studied throughout the second oestrous cycle of the breeding season by daily transrectal ultrasonographic examinations during September and October. Ovarian images were obtained with a B-mode scanner (Aloka SSD 500, Overseas Monitor Corp. Ltd, Richmond, BC) equipped with a rigid $7.5 \mathrm{MHz}$ transducer (shaft length, $35 \mathrm{~cm}$; shaft diameter, $1.6 \mathrm{~cm}$ ), which was designed for transrectal prostate examination in humans and has been validated for the present application in sheep (Schrick et al., 1993).

The transducer was manipulated externally, with the ewe in the standing position in a raised wooden crate and placed in a cattle squeeze chute. The image on the scanner was obtained at $\times 1.5$ magnification. At this magnification, ovarian follicles $\geqslant 1 \mathrm{~mm}$ were detected. However, to reduce error, diameter and position in both ovaries of only those follicles $\geqslant 2 \mathrm{~mm}$ in diameter were recorded daily, as previously described and validated for cattle (Pierson and Ginther, 1987; Knopf et al., 1989) and sheep (Schrick et al., 1993). Similarly, the diameter and position of corpora lutea were also recorded. Examinations were carried out daily between 08:00 and 10:00 h. The ovaries of one ewe were scanned in vivo to confirm the validity of our methodology; they were then re-scanned in a water bath after the ewe was killed and the ovaries were examined (Schrick et al., 1993) by dissection. All three methods gave similar results. Blood samples $(5 \mathrm{ml})$ were collected once a day by jugular venepuncture from all the ewes throughout the period of study. Serum was stored frozen at $-20^{\circ} \mathrm{C}$ until analysed.

\section{Hormone analysis}

Serum samples were analysed by radioimmunoassay for concentrations of FSH (Rawlings et al., 1984; Currie and Rawlings, 1989), oestradiol (Joseph et al., 1991) and progesterone (Rawlings et al., 1984). Samples were analysed for FSH in a single assay and the FSH concentrations expressed in terms of NIDDK-oFSH-RP1. The sensitivity of the assays was defined as the lowest standard different from zero $(P<0.05)$ using an unpaired $t$ test. Sensitivity was $0.25 \mathrm{ng} \mathrm{ml}^{-1}$ serum for the FSH assay and $3.67 \mathrm{pmol}^{-1}$ and $0.32 \mathrm{nmol}^{-1}$ for the oestradiol and progesterone assays, respectively. The range of standards used in the FSH, oestradiol and progesterone assays were $0.125-16 \mathrm{ng} \mathrm{ml}-1,3.67-367 \mathrm{pmol} \mathrm{I}^{-1}$ and $0.32-$ $32.0 \mathrm{nmol} 1^{-1}$, respectively. The intra-assay coefficients of variation for ovine reference sera with mean FSH concentrations of $1.53 \mathrm{ng}$ or $4.25 \mathrm{ng} \mathrm{ml} \mathrm{m}^{-1}$ were 3.4 or $5.4 \%$, respectively. The intra-assay and interassay coefficients of variation for ovine reference sera with oestradiol concentrations of 25.87 or $56.67 \mathrm{pmol}^{-1}$ were 14.8 and $8.7 \%$ or 18.7 and $11.1 \%$, respectively. The intra-assay and interassay coefficients of variation for ovine reference sera with progesterone concentrations of 2.45 or $10.11 \mathrm{nmol} \mathrm{l}^{-1}$ were 11.3 and $9.3 \%$ or 14.9 and $12.8 \%$, respectively. All of the follicle and hormone data from the eight ewes were aligned to the day of ovulation (day 0) for presentation.

\section{Follicle data analysis}

Ovarian follicle data were analysed for one interovulatory interval (cycle). The day of ovulation was regarded as the day on which a large growing antral follicle that had previously been identified and followed for several days was no longer seen. The timing of ovulation was further confirmed by detection of oestrus by the rams. The total numbers of follicles $\geqslant 2$ and $\geqslant 3 \mathrm{~mm}$ in diameter were assessed on each day. All the follicles in individual ewes were traced retrospectively to the day on which they were $2 \mathrm{~mm}$ in diameter; this was regarded as the day of emergence or day of growth into the size range to be monitored. For the purpose of analysis of follicle emergence, only the follicles that grew to a diameter of at least $4 \mathrm{~mm}$, or could be identified for at least 4 days and that changed in diameter by at least $1 \mathrm{~mm}$ over this time, were included. The numbers of follicles emerging on each day of the cycle were tabulated. The duration of growth of a follicle was the time taken by that follicle to grow from $2 \mathrm{~mm}$ in diameter to its maximum diameter. The duration of regression of a follicle was the time taken by that follicle to regress from its maximum diameter to $2 \mathrm{~mm}$ in diameter. The period between the end of the growing phase and the start of regression or ovulation was the static phase. The mean diameter of the largest follicle and diameters of corpora lutea were analysed for each day of the cycle. Ovulatory follicles emerged on day 9 or later in the cycle, with a peak emergence on day 11. The 

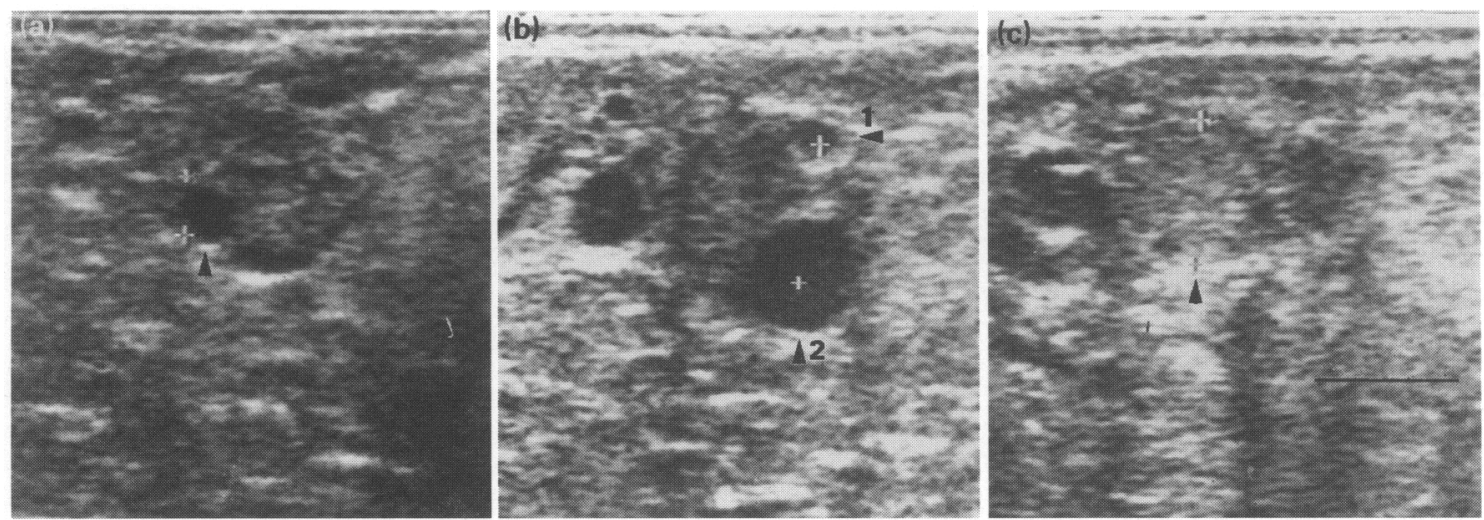

Fig. 1. Photograph of ultrasound images of ovaries of ewes produced using a rigid, transrectal, $7.5 \mathrm{MHz}$ human prostate transducer. Images were obtained using a B-mode scanner at $\times 1.5$ magnification. (a) The arrowhead indicates an antral follicle of $4 \mathrm{~mm}$ in diameter. (b) Arrowhead 1 indicates an antral follicle of $2 \mathrm{~mm}$ in diameter; arrowhead 2 indicates a follicle $8 \mathrm{~mm}$ in diameter. (c) The arrowhead indicates a functioning corpus luteum $10 \mathrm{~mm}$ in diameter. Scale bar represents $10 \mathrm{~mm}$.

growth curves of the ovulatory follicle and the next largest follicle emerging in this later period of the cycle were normalized to the mean day of emergence of the ovulatory follicle for illustrative purposes. Similarly, there was a peak in follicle emergence on day 2 of the cycle, with no follicles emerging on day $I$ or day 5 . The growth curves for the largest and the next largest follicles emerging in this period of time were normalized to day 2 of the cycle for illustration.

\section{Statistical analyses}

Mean diameters of the largest follicles, diameters of the corpora lutea, the mean total number of follicles $\geqslant 2 \mathrm{~mm}$ and $\geqslant 3 \mathrm{~mm}$ in diameter, the number of follicles emerging each day, and the mean daily concentrations of progesterone, oestradiol and FSH were analysed by a repeated measures analysis of variance (ANOVA), with Fisher's protected least significant difference (LSD) as the post-ANOvA test (Statview, 1986). The characteristics of growth and regression and maximum diameter of the largest and second largest follicles emerging at about day 2 and day 11 of the cycle and the largest follicle emerging in the intervening period (days 6-8 inclusive) were compared by paired $t$ test.

\section{Results}

\section{Follicle dynamics}

Photographs of images of ovarian structures recorded in this study are shown in Fig. 1. The mean interovulatory interval was $17.2 \pm 0.4$ days $(n=8)$, and the mean day of emergence of the ovulatory follicle was day $11.1 \pm 0.3$ of the cycle. Follicle emergence occurred on all the days of the interovulatory interval (cycie) except for days 1, 5, 15, 16 and 17 (days 0 and 17 were the days of ovulation; Figs 2, 3a). However, significantly more $(P<0.05)$ follicles emerged at about days 2 and 11 . On day 2 , more follicles emerged per ewe $(P<0.05)$ than on days $0,1,4,5,14,15,16$ and 17 . On day 11, follicle emergence was significantly greater $(P<0.05)$ than on all days except for day $2(P>0.05)$. Six out of eight and seven out of eight ewes showed follicle emergence on days 2 and II, respectively. During the oestrous cycle the total number of follicles $\geqslant 2 \mathrm{~mm}$ in diameter increased from early to midcycle and fell from day 13 to day 17 of the cycle $(P<0.05$; Fig. $3 b$ ). The total number of follicles $\geqslant 3 \mathrm{~mm}$ in diameter increased from the early to the late part of the cycle but decreased from day 16 to day $17(P<0.05$; Fig. 3b). The diameter of the largest follicle was low from ovulation (day 0 ) to day 3 of the cycle, increased to day 5 and rose to a second peak at day 16 , before decreasing to a nadir at day 17 $(P<0.05$; Fig. 3c).

Growth and regression characteristics and maximum diameters of the largest and second largest follicles emerging at about day 2 and day 11 of the cycle, and the largest follicle emerging in the intervening period (days 6-8 inclusive) are shown (Table 1 and Fig. 4). The growth rates of follicles emerging late in the cycle were greater than those emerging early in the cycle, and follicles emerging in mid-cycle had intermediate values $(P<0.05$; Table 1$)$. The duration of growth of the ovulating follicle was greater than that of all other follicles, and the second largest follicle emerging early in the cycle had the shortest growth period $(P<0.05$; Table 1$)$. Regression rates did not vary among follicles emerging at different times in the cycle $(P>0.05)$. The regression was longest for the largest nonovulating follicle emerging late in the cycle, followed by the largest follicle emerging early in the cycle, the second largest follicle early in the cycle and the follicle emerging mid-cycle $(P<0.05$; Table 1$)$. Maximum follicle diameter was greatest for the ovulating follicle; the next largest follicle emerging late in the cycle and the largest follicle emerging early in the cycle had similar but smaller maximum diameters. The second largest follicle emerging in the early part of the cycle and follicles emerging mid-cycle were similar in size but reached the smallest maximum diameters $(P<0.05$; Table 1). Only $34 \%$ of follicles showed a static phase in their growth curve and the average duration of this phase for those follicles was $1.3 \pm 0.2$ days. 

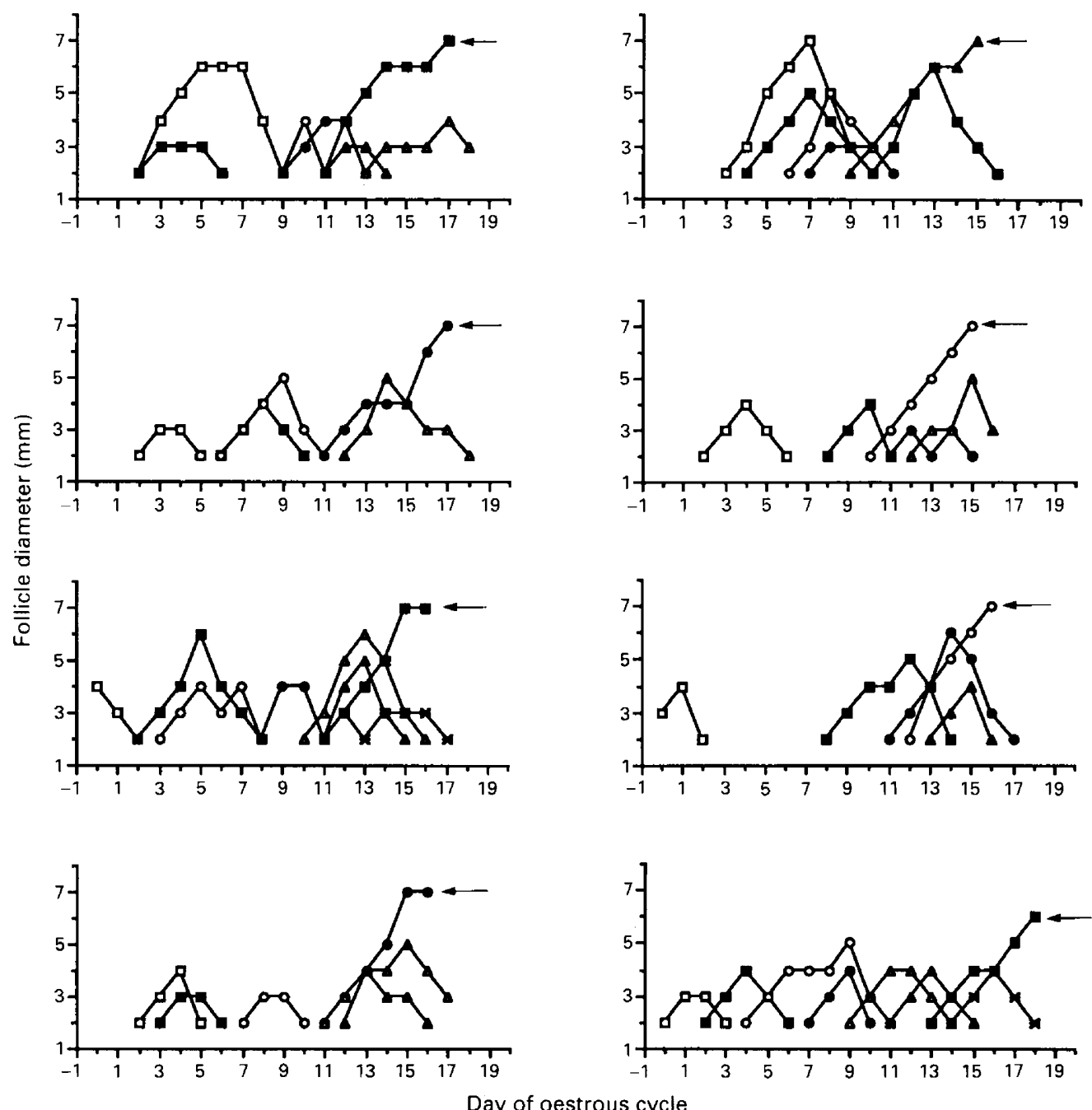

Fig. 2. The growth curves of all follicles emerging or growing from the pool of follicles $\geqslant 2 \mathrm{~mm}$ in diameter throughout the oestrous cycle in the eight ewes studied. The arrows indicate the diameter of the ovulatory follicle on the day before ovulation. The number, size and location of all follicles $\geqslant 2 \mathrm{~mm}$ in diameter were recorded daily to the nearest $1 \mathrm{~mm}$ and the growth curves of individual follicles constructed retrospectively based on the daily mapping.

\section{Corpus luteum and progesterone}

The functioning corpora lutea of the oestrous cycle could be detected ultrasonographically in all the ewes, from day 3 onwards, although in three of the ewes it could be seen on day 2 as a structure $8-10 \mathrm{~mm}$ in diameter (Fig. $5 \mathrm{a}$ ). The mean diameter of the corpora lutea increased from $11.5 \pm 0.3 \mathrm{~mm}$ on day 3 of the cycle $(P<0.05)$ to $13.3 \pm 0.6 \mathrm{~mm}$ by day 5 ; there was no significant change in diameter between days 5 and 10 $(P>0.05)$. From a diameter of $11.7 \pm 0.4 \mathrm{~mm}$ on day 11 , the size of the corpora lutea decreased to $9.9 \pm 0.4 \mathrm{~mm}$ by day 14 $(P<0.05)$ and $7.5 \pm 0.3 \mathrm{~mm}$ on day 17 (day of ovulation). Mean serum progesterone concentrations rose gradually to reach a peak of $14.2 \pm 2.1 \mathrm{nmol}^{-1}$ on day 10 of the cycle $(P<0.05$; Fig. 5a). Serum progesterone concentrations started to decline on day 11 (11.2 $\left.\pm 1.0 \mathrm{nmol} \mathrm{I}^{-1}\right)$, coinciding with the start in decline in corpora lutea diameter, to reach a low level of $0.83 \pm 0.2 \mathrm{nmol} \mathrm{l}^{-1}(P<0.05)$ on the day of ovulation.

\section{Serum concentrations of oestradiol}

Mean serum oestradiol concentrations (Fig. 5b) showed a gradual increase from a low on day 11 (I1.8 $\pm 1.1 \mathrm{pmol}^{-1}$ ) to reach a peak of $31.1 \pm 3.7 \mathrm{pmol}^{-1}$ on the day before ovulation. They declined to $10.7 \pm 1.5 \mathrm{pmol}^{-1}$ on day 17 (ovulation day; $P<0.05$ ). Serum concentrations of oestradiol were quite variable during the remainder of the oestrous cycle (Fig. 5b).

\section{Serum concentrations of FSH}

Mean serum FSH concentrations (Fig. 5b) on day 16 were significantly higher $(P<0.05)$ than on days $2,10,11,13,14,15$ and 17 , but were not different from that on days $1,3-9$ and 12 $(P>0.05)$. Serum FSH concentrations reached a significant nadir on day 14 of the cycle, remaining low on day 15 $(P<0.05)$. 

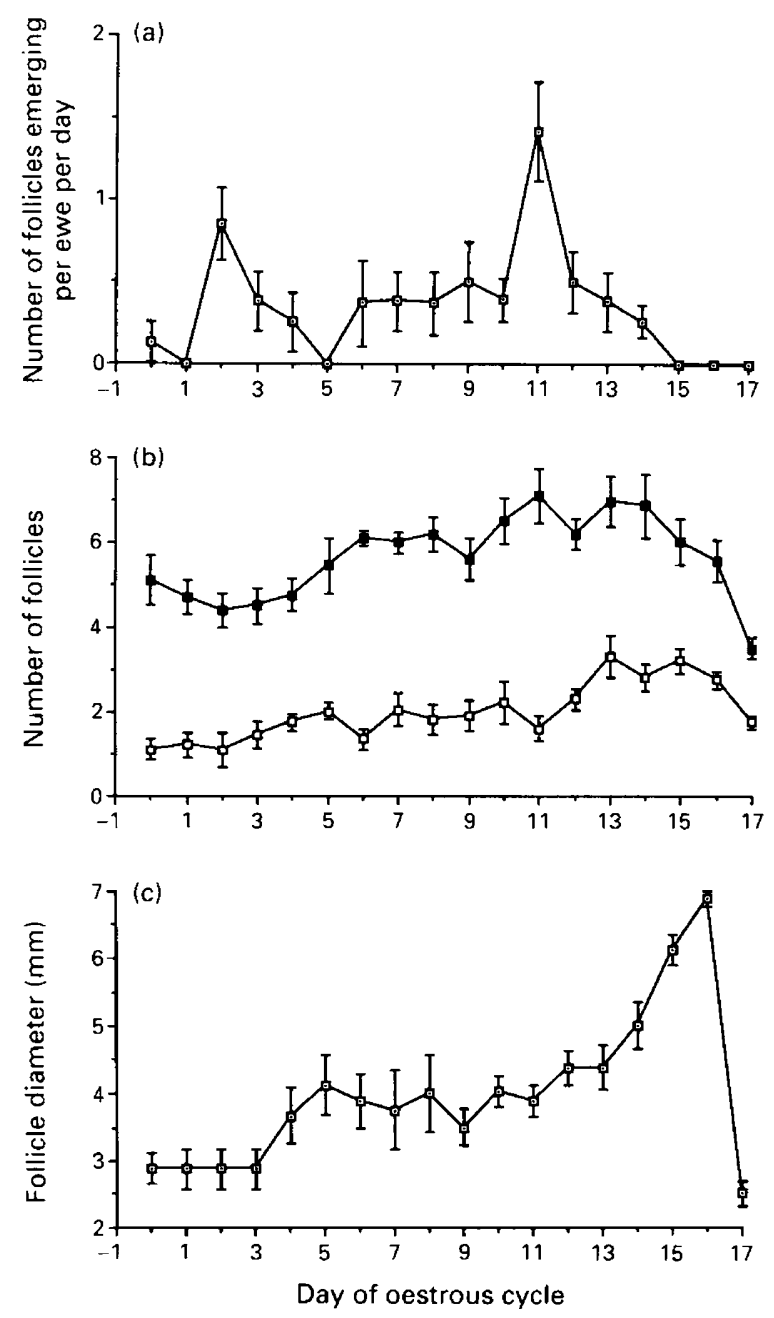

Fig. 3. Ovarian antral follicle dynamics in ewes during the interovulatory interval. (a) The number of follicles (mean \pm SEM) emerging (starting to grow $>2 \mathrm{~mm}$ in diameter) per ewe on each day throughout the oestrous cycle. No follicles emerged in any of the eight ewes on days 1, 5, 15, 16 and 17. There were peaks of emergence on days 2 and 11. Only the follicles that could be identified for at least 3 consecutive days and grew to at least $4 \mathrm{~mm}$ in diameter or were identified for at least 4 consecutive days and grew to at least $3 \mathrm{~mm}$ in diameter, were included. (b) Total number of follicles $\geqslant 2 \mathrm{~mm}$ in diameter ( - ) and $\geqslant 3 \mathrm{~mm}$ in diameter (o) throughout the oestrous cycle. All the follicles detected on any day, whether or not seen on subsequent days, were included. Mean number of follicles $\geqslant 2 \mathrm{~mm}$ in diameter increased gradually to mid-cycle and had fallen significantly by day $17 \quad(P<0.05)$. The mean number of follicles $\geqslant 3 \mathrm{~mm}$ in diameter increased significantly up to the late part of the cycle and had fallen significantly by day $17(P<0.05)$. (c) The mean diameter of the largest follicles throughout the oestrous cycle. The mean diameter of the largest follicles remained low until day 3 , rose to day 5 , reached a peak on day 16 , only to fall to a nadir on day $17(P<0.05)$.

\section{Discussion}

Ultrasonographic studies in cattle have shown that growth of large antral follicles occurs in two or three distinct waves during the oestrous cycle. Each wave is characterized by simultaneous emergence of follicles from a pool of small follicles and establishment of a dominant follicle that continues to develop, while apparently suppressing the growth of other follicles (subordinates). The growth of the dominant follicle is consistently associated with a reduction in both the number and growth of the subordinate follicles (Fortune et al., 1988, 1991; Pierson and Ginther, 1988; Savio et al., 1988; Sirois and Fortune, 1988; Knopf et al., 1989; Webb et al., 1992). Previous studies of the growth of large antral follicles during the oestrous cycle in ewes have been largely restricted to observations at slaughter or limited periods of repeated observations using laparotomy or laparoscopy. Such studies have suggested that antral follicles are present in the ovaries of ewes throughout the oestrous cycle (Cahill and Mauleon, 1980; McNatty et al., 1984, 1985; Webb and Gauld, 1985). However, previous data led to conclusions that antral follicles grow early in the cycle and then remain in the ovary to enlarge before ovulation (Hutchinson and Robertson, 1966), or that there may be two, three or more phases of antral follicle growth during the cycle (Smeaton and Robertson, 1971; Brand and de Jong, 1973).

Our data showed antral follicles emerging or growing from a pool of follicles $\geqslant 2 \mathrm{~mm}$ in diameter on all days of the cycle except days $1,5,15,16$ and 17 . However, significantly more follicles emerged on days 2 and 11 of the cycle. There appeared to be two major phases of growth of large antral follicles in the ewes. In a recent study that used ultrasonography in ewes after oestrus synchronized by $\mathrm{PGF}_{2 \alpha^{\prime}}$ the authors concluded that follicle emergence above $2 \mathrm{~mm}$ in diameter was a continuum across the oestrous cycle, but that a peak occurred on day 2 (Schrick et al., 1993). The two phases of follicle emergence observed in this study may reflect the waves of growth seen in cattle. However, the significant changes in numbers of antral follicles and emergence of follicles associated with waves of follicular growth in cattle were not seen in the ewes in the present study. The follicular dominance associated with follicular growth waves in cattle was also not prominent in our data.

In the present study, the observations made on follicle growth and regression patterns, follicle diameters and total numbers suggest that follicular dominance is a weak phenomenon in sheep in contrast to the situation in cattle. This contention supports the views of Schrick et al. (1993), who studied ovarian follicular growth in cyclic ewes by ultrasonography. In cattle, the dominant follicle has been shown to be larger than the subordinate follicle from the second day of the wave of follicle growth. The subordinate follicle ceases to grow 4.4 days after the start of a wave, while the dominant follicle grows linearly (Ginther et al., 1989). In addition, in cattle, dominance is also assumed because the growth of a large number of small follicles emerging with the dominant follicle is also rapidly suppressed. In the ewes studied here, the total number of follicles $\geqslant 2 \mathrm{~mm}$ diameter fell significantly only near ovulation, when the ovulating follicle seemed to have suppressed the growth of other ovarian follicles. This suppression was noted only fairly late in the growth phase of follicles emerging at about the time of the ovulating follicle (day 15 of the cycle, after luteolysis). During the luteal phase of the oestrous cycle, the largest follicle growing from day 2 of the cycle may have exerted dominance over the next largest 
Table 1. Growth and regression characteristics and maximum diameters of the largest and second largest follicles emerging at about day 2 and day 11 of the oestrous cycle in ewes and the largest follicle emerging in the intervening period (days 6-8 inclusive)

\begin{tabular}{|c|c|c|c|c|c|}
\hline \multirow{2}{*}{$\begin{array}{l}\text { Growth and } \\
\text { regression } \\
\text { characteristics }\end{array}$} & \multicolumn{2}{|c|}{ Follicles emerging between days 2 and 4 of cycle } & \multicolumn{2}{|c|}{ Follicles emerging after day 9 of cycle } & \multirow{2}{*}{$\begin{array}{l}\text { Largest } \\
\text { follicle } \\
\text { emerging in } \\
\text { mid-cycle* }\end{array}$} \\
\hline & Largest & Second largest & Largest (ovulatory) & Second largest & \\
\hline Duration of growth (days) & $2.9 \pm 0.2^{b}$ & $1.9 \pm 0.2^{c}$ & $4.1 \pm 0.1^{\mathrm{a}}$ & $2.5 \pm 0.2^{b}$ & $2.0 \pm 0.2^{b c}$ \\
\hline Growth rate $\left(\mathrm{mm} \mathrm{day}^{-1}\right)$ & $1.0 \pm 0.0^{b}$ & $0.9 \pm 0.06^{\mathrm{b}}$ & $1.2 \pm 0.4^{\mathrm{a}}$ & $1.1 \pm 0.07^{\mathrm{a}}$ & $1.1 \pm 0.08^{\mathrm{ab}}$ \\
\hline Duration of regression (days) & $2.4 \pm 0.2^{\mathrm{b}}$ & $1.8 \pm 0.3^{c}$ & - & $2.6 \pm 0.2^{\mathrm{a}}$ & $1.6 \pm 0.3^{c}$ \\
\hline Rate of regression $\left(\mathrm{mm} \mathrm{day}^{-1}\right)$ & $1.1 \pm 0.06^{\mathrm{a}}$ & $1.1 \pm 0.15^{\mathrm{a}}$ & - & $1.2 \pm 0.07^{\mathrm{a}}$ & $1.4 \pm 0.2^{\mathrm{a}}$ \\
\hline Maximum diameter (mm) & $5.5 \pm 0.3^{b}$ & $4.4 \pm 0.2^{\mathrm{c}}$ & $6.9 \pm 0.1^{\mathrm{a}}$ & $5.1 \pm 0.3^{b}$ & $4.3 \pm 0.3^{c}$ \\
\hline
\end{tabular}

All values are means $\pm \operatorname{SEM}(n=8)$.

Values with different superscripts within rows are significantly different $(P<0.05)$.

*Days $6-8$ of the cycle.

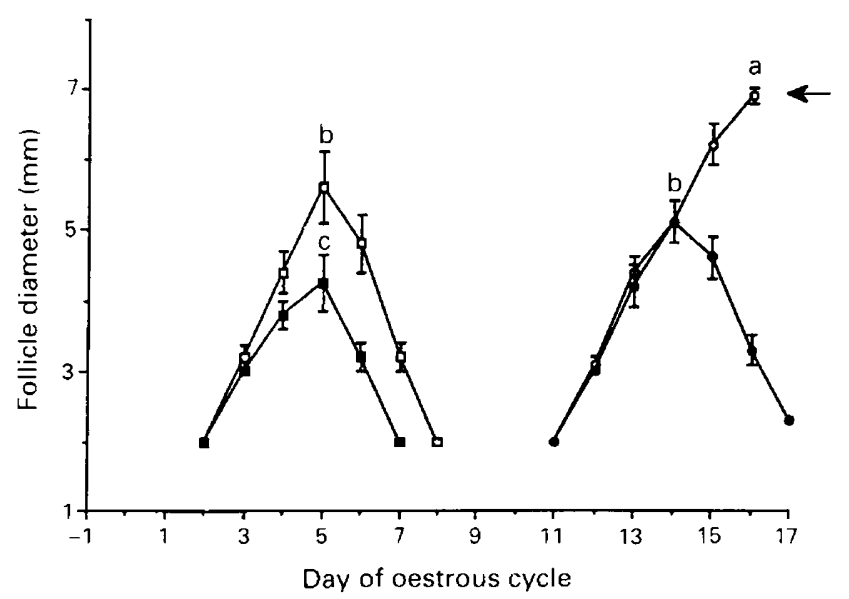

Fig. 4. Diameters (mean \pm SEM) of the two largest follicles emerging at about day 2 (normalized to day 2: $0,-$ ) and day 11 (normalized to day $11 ; 0, \bullet)$ of the oestrous cycle in ewes. The arrow indicates the diameter of the ovulating follicle on the day before ovulation. Diameters with different letters are significantly different $(P<0.05)$.

follicle, but compared with the definition of dominance in cattle, this dominance was very weak.

Data from slaughtered ewes (Brand and de Jong, 1973) revealed no systematic variation in the absolute or relative numbers of normal and atretic tertiary follicles during the oestrous cycle of ewes. This was also true when the follicles were subdivided into classes according to stage of atresia. However, the total number of follicles $\geqslant 2 \mathrm{~mm}$ in diameter, reported in the study above, and in other studies (Driancourt et al., 1988; Schrick et al., 1993), seemed higher than observed in the present study. The fewer follicles in our study may reflect breed differences and also the stage of the breeding season at which studies were undertaken. The oestrous cycle described here was for relatively non-prolific Western WhiteFace ewes and it was the second cycle of the breeding season. Ovulation rate increases to mid-breeding season (Ortavant et al., 1988), when the studies mentioned above were performed (Driancourt et al., 1988; Schrick et al., 1993). Schrick et al. (1993) reported a marked increase in numbers of follicles from October to November.

In the study reported here, the similarity of growth rates of the two largest follicles growing in the early period of the oestrous cycle and the lack of a significant fall in the number of follicles during any time, except near ovulation, indicated a lack of or only a weak dominance and a pattern of growth and regression of follicles that is not as distinctly wave-like as in cattle. However, increased emergence and growth of follicles during two periods of the cycle did show a tendency for two phases of growth and regression. The fact that dominance is weak or absent in sheep may be logical, since sheep are multiple ovulators and so more than one follicle should retain the potential to ovulate until late in the oestrous cycle. From a recent study (Castonguay et al., 1990), it was concluded that dominance by the largest follicle was not present in ewes of prolific genotypes; this was based on the finding that there was no difference in oestrus and ovulation rates between control ewes and ewes in which the largest follicle was destroyed, following withdrawal of progesterone-impregnated sponges.

The ovulatory follicles emerged on day $11.1 \pm 0.3$ and grew over a period of $4.1 \pm 0.1$ days at a rate of $1.2 \pm 0.04 \mathrm{~mm}$ day $^{-1}$. This was at a time when serum progesterone concentrations started to decline, from a peak on day' 10 of the oestrous cycle. These results are in contrast to the data collected from ewes killed at different times of the oestrous cycle, from which it was concluded that the ovulatory follicle increased in size markedly from early metoestrus to the early luteal phase and thereafter remained at this size until preovulatory enlargement at oestrus (Hutchinson and Robertson, 1966). Other studies showed results similar to those reported here, in that the ovulatory follicle was derived from a pool of follicles $>2 \mathrm{~mm}$ in diameter at the time of luteolysis and emerged as a growing oestrogenic follicle within $10 \mathrm{~h}$ of luteolysis (McNatty et al., 1982; Driancourt et al., 1986; Webb et al., 1989). In a study using ultrasonography in ewes, it appeared that the ovulatory follicle grew beyond $2 \mathrm{~mm}$ in diameter at about day 11 of the oestrous cycle (Schrick et al., 1993). 

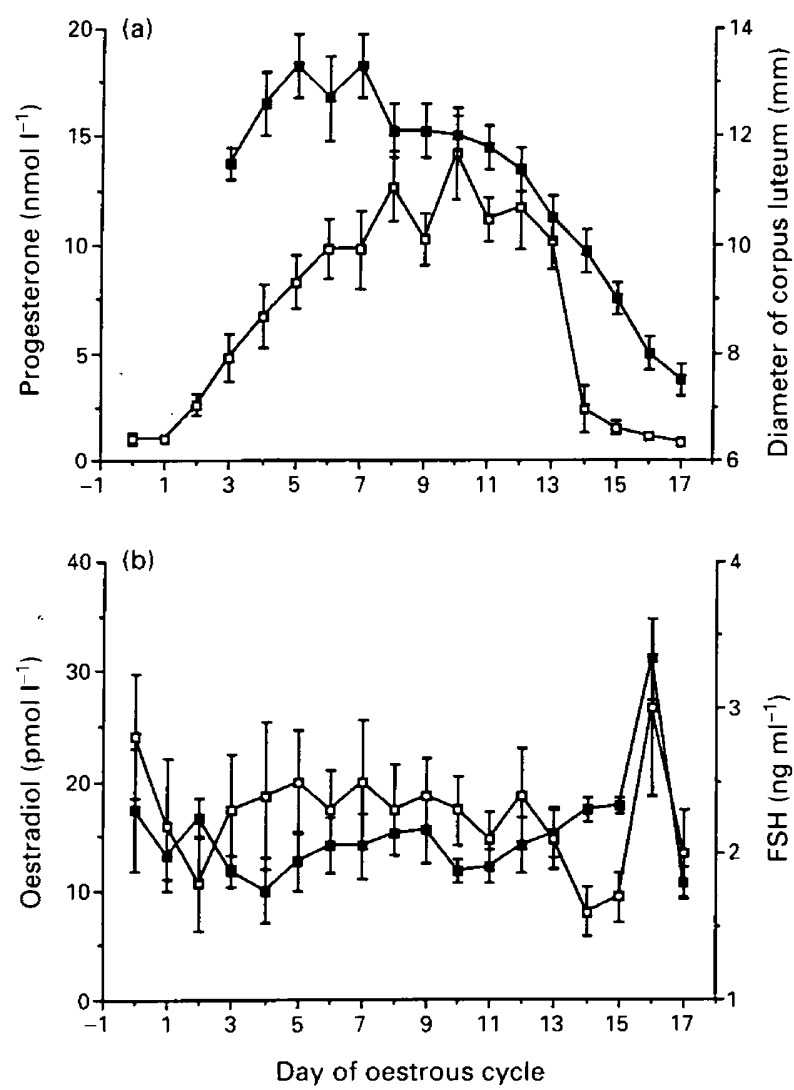

Fig. 5. (a) Mean ( $n=8$ ) serum concentrations of progesterone ( $\square$ ) from daily blood samples throughout the oestrous cycle of ewes and the mean $(n=8)$ diameters of the corpora lutea ( $)$ from day 3 to day 17 (day of ovulation) of the oestrous cycle of ewes. The mean progesterone concentration increased significantly to reach a peak on day 10 of the cycle, started to decline on day $I I$ and reached a significantly low concentration on day $17(P<0.05)$. The mean diameter of corpora lutea significantly increased to day 5, and decreased from day 11 to day $17(P<0.05)$. (b) Mean serum concentrations of FSH $(\square ; n=8)$ and oestradiol ( $n ; n=7$ ) from daily biood samples throughout the oestrous cycle of ewes (mean \pm SEM). Mean concentrations of FSH showed minor fluctuations during the early and middle parts of the cycle, fell significantly on day 14 , and were low by day 15 . There was a significant peak on day 16 and a subsequent nadir on day 17 $(P<0.05)$. Mean oestradiol concentration showed a gradual increase from a low on day 11 to a peak on day 16 and had fallen significantly by day $17(P<0.05)$. Concentrations were quite variable during the remainder of the oestrous cycle.

The growth rate of the ovulatory follicle in our study was similar to that observed by Driancourt and Cahill (1984) in a study involving treatment of ewes with $\mathrm{PGF}_{2 a}$ and observation of follicles by laparotomy. The ovulatory follicle in their study increased in diameter at a rate of $1.42 \pm 0.9 \mathrm{~mm} \mathrm{day}^{-1}$ between 6 and $30 \mathrm{~h}$ after $\mathrm{PGF}_{2 a}$ treatment and $0.38 \pm 0.41 \mathrm{~mm}$ day ${ }^{-1}$ between 30 and $54 \mathrm{~h}$ after $\mathrm{PGF}_{2 a}$ treatment. The growth of the ovulatory follicle was slower in the second period, which is similar to the observation in the study reported here of a static phase of growth in some but not all follicles. Follicle growth rates ranging from $0.9 \mathrm{~mm}^{-1}$ day $^{-1}$ to $1.7 \mathrm{~mm}$ day $^{-1}$, have been observed in different breeds of sheep (Driancourt et al., 1986; Castonguay et al., 1990). Follicle regression rates observed in the study reported here appeared to be slightly lower than those in an earlier report (1.6 $\pm 0.6 \mathrm{~mm} \mathrm{day}^{-1}$; Driancourt and Cahill, 1984) for follicles in a follicular phase induced by $\mathrm{PGF}_{2 \alpha^{\prime}}$ with observations made at laparotomy.

In the study reported here, which involved white-faced, cross-bred ewes, the mean maximum diameter of the ovulating follicle was $6.9 \pm 0.1 \mathrm{~mm}$. From several previous studies (Brand and de Jong, 1973; Driancourt and Cahill, 1984; Driancourt et al., 1988, 1990) either at slaughter, or at repeated laparotomies, with normal or prostaglandin-induced oestrus, a range of 4-10 $\mathrm{mm}$ has been reported as the maximum diameter of the ovulatory follicle. These studies involved breeds different from that used in the study reported here, with different ovulation rates. The ewes in this study ovulated only one follicle in the oestrous cycle examined; this is probably a reflection of the fact that this was only the second cycle of the breeding season and the ewes we used were from a non-prolific breed.

Several studies that measured oestradiol concentrations in the utero-ovarian venous blood, with samples taken daily or several times a day, have examined oestradiol secretion and ovarian follicular development. At any stage of the oestrous cycle most of the oestradiol comes from the largest non-atretic follicle in the ovary (Bjersing et al., 1972). A peak of oestradiol on the day before ovulation was noted in our study as has been noted by Scaramuzzi et al. (1970) and Cox et al. (1971). Additional peaks of oestradiol on days 3 and 4 (Cox et al., 1971) and days 6-9 of the cycle (Scaramuzzi et al., 1970; Mattner and Braden, 1972) have been shown to occur, suggesting phases of follicular development at these times during the oestrous cycle. Variability in the secretion of oestradiol during the luteal phase in ewes has also been demonstrated by Baird et al. (1976); this did not support a distinct wave-like pattern of development of follicles throughout the luteal phase.

In the study reported here, fluctuations in serum concentrations of oestradiol were quite variable during most of the oestrous cycle, supporting the data on follicles that showed emergence and growth of follicles on most days of the cycle. There was no particular increase in serum concentration of oestradiol due to the peak in follicle emergence on day 2 of the cycle. Only the late preovulatory follicle produced a significant peak in serum concentrations of oestradiol, as measured in serum samples from jugular blood. There must be oestrogenic follicles at other stages of the cycle but these must lack a gonadotrophic stimulus during the luteal phase to produce maximum amounts of oestradiol.

Evidence from blood sampling performed once or twice a day and FSH radioimmunoassay (Adams et al., 1992, 1994) shows that an increase in FSH secretion is associated with each of the two or three follicular waves in the oestrous cycle of cattle. However, in the present study, only a peak in serum concentration of FSH was seen at about oestrus. With the present blood sample collection protocol (daily samples) we could not delineate the secondary metoestrous increase in serum FSH concentration that has been reported by others (Dobson and Ward, 1977; Pant et al., 1977; Baird and McNeilly, 1981; Medhamurthy et al., 1987). 
The importance of FSH in ovarian folliculogenesis in ewes has already been demonstrated (Dufour et al., 1979; McNeilly et al., 1986; Hunter et al., 1988; Baird et al., 1990). However, it is not yet clear whether fluctuations in FSH concentrations during the interovulatory period are important for the emergence of follicles. The results of the present study appear to indicate that a distinct increase is not needed for follicle emergence or growth into the antral follicle size ranges we studied. It must be stressed that we studied only follicles $\geqslant 2 \mathrm{~mm}$ in diameter; endocrine-regulated recruitment and selection may occur in smaller follicles. A fall in FSH concentration did occur in the early follicular phase, which was similar to an earlier report (Cahill et al., 1981). This indicated that growth of the ovulatory follicle occurred under conditions of reduced FSH secretion. It has been suggested that this fall in FSH occurs as a result of enhanced negative feedback by oestradiol and inhibin (Martin et al., 1988), and a factor in the selection of the ovulatory follicle may be the withdrawal of FSH from all other potential ovulatory follicles. However, it has been suggested by recent studies that this fall in circulating FSH concentration may not be sufficient for selection of the preovulatory follicle and that LH may also be important in this process (Campbell et al., 1990; McNeilly et al., 1991, 1992; Picton and McNeilly 1991). In the study reported here, the ovulatory follicle grew to a significantly greater diameter over a longer duration than did any other follicle during the oestrous cycle. Its growth rate, as well as that of the next largest follicle of the same period, was also significantly greater than that of the follicles emerging on day 2 . This may be indicative of the importance of $\mathrm{LH}$ for antral follicle growth. LH secretion is suppressed by higher progesterone concentrations in the luteal phase and this suppression is withdrawn following luteolysis.

Observations on growth of corpora lutea and regression in ewes slaughtered at different times during the oestrous cycle (Hutchinson and Robertson, 1966) indicated that they increased in size sharply between $36 \mathrm{~h}$ and 5 days after the onset of oestrus. The increase in size from day 5 to day 10 was slow, yet significant; after that, the corpora lutea began to regress (Hutchinson and Robertson, 1966). The corpora lutea were recognizable by transrectal ultrasonography in all the ewes in the present study by day 3 (day 0, day of ovulation), and had increased significantly in diameter by day 5 . Contrary to the observations of Hutchinson and Robertson (1966), a significant increase in diameter between days 5 and 10 of the oestrous cycle was not found. However, the serum progesterone concentrations increased to give a peak on day 10. In agreement with the observations of Hutchinson and Robertson (1966), corpora lutea in our ewes started to decrease in diameter from day 11 onwards. Schrick $e t$ al. (1993) found that they increased rapidly in size to day 8 of the oestrous cycle but otherwise our data for corpora lutea diameter and serum concentrations of progesterone are similar to theirs.

In conclusion, ultrasonography as used in cattle, with some modifications, can be reliably used in sheep for the study of ovarian follicular dynamics. Our results suggest that ovarian antral follicular growth (follicles $\geqslant 2 \mathrm{~mm}$ diameter) and regression occurs at most stages of the oestrous cycle of ewes and that follicles emerge on many days throughout the oestrous cycle. Although distinct waves of follicular growth and regression, as defined for cattle, were not evident in the ewes, there were two significant peaks in follicle emergence at about days 2 and 11. There was no correlation between the pattern of FSH secretion during the oestrous cycle and follicle emergence and growth. Dominance by large follicles was not clearly evident in the ewes studied here, based on the definition of dominance developed for cattle (Ginther et al., 1989), and the pattern of growth and regression of the two largest follicles during the early and late periods of the oestrous cycle and number of follicles during the cycle in the ewes studied here. However, during the late follicular phase (after day 14 of the cycle and luteolysis) the ovulatory follicle appeared to suppress the number of follicles and the growth of other follicles.

The authors thank S. J. Cook for technical assistance, W. M. Kerr and staff for care and management of the animals and NIDDK and USDA for provision of the purified hormones. This research was funded by a National Science and Engineering Research council of Canada grant to N. C. Rawlings. J. P. Ravindra and A. C. O. Evans are supported by University of Saskatchewan Graduate Student Scholarships.

\section{References}

Adams GP, Matteri RL, Kastelic JP, Ko JCH and Ginther OJ (1992) Association between surges of follicle-stimulating hormone and the emergence of follicular waves in heifers Journal of Reproduction and Fertility 94 177-188

Adams GP, Evans ACO, and Rawlings NC (1994) Follicular waves and circulating gonadotrophins in 8-month-old-prepubertal heifers Joumal of Reproduction and Fertility 100 27-33

Baird DT and McNeilly AS (1981) Gonadotrophic control of follicular development and function during the oestrous cycle of the ewe Journal of Reproduction and Fertility Supplement 30 119-133

Baird DT, Land RB, Scaramuzzi RJ and Wheeler AG (1976) Endocrine changes associated with luteal regression in the ewe; the secretion of ovarian oestradiol, progesterone and androstenedione and uterine prostaglandin $\mathrm{F}_{2 \alpha}$ throughout the oestrous cycle Journal of Endocrinology 69 275-286

Baird DT, Campbell BK, Mann GE and McNeilly AS (1990) The role of inhibin and oestradiol in the regulation of FSH secretion in the ewe Journal of Reproduction and Fertility 43 125-138

Bjersing L, Hay MF, Kann G, Moor RM, Naftolin F, Scaramuzzi RJ, Short RV and Younglai EV (1972) Changes in gonadotrophins, ovarian steroids and follicular morphology in sheep at oestrus Journal of Endocrinology 52 465-479

Brand A and de Jong WHR (1973) Qualitative and quantitative micromorphological investigations of the tertiary follicle population during the oestrous cycle in sheep Joumal of Reproduction and Fertility 33 431-439

Cahill LP and Mauleon P (1980) Influences of season, cycle and breed on follicular growth rates in sheep Journal of Reproduction and Fertility $\mathbf{5 8}$ $321-328$

Cahill LP, Mariana JC and Mauleon P (1979) Total follicular population in ewes of high and low ovulation rates Journal of Reproduction and Fertility $\mathbf{5 5}$ $27-36$

Cahill LP, Saumande J, Ravault JP, Blanc M, Thimonier J, Mariana JC and Mauleon P (1981) Hormonal and follicular relationships in ewes of high and low ovulation rates Journal of Reproduction and Fertility 62 141-150

Campbell BK, McNeilly AS, Picton HM and Baird DT (1990) The effect of a potent GnRH antagonist on ovarian secretion of oestradiol, inhibin and androstenedione and the concentration of $\mathrm{LH}$ and FSH during the follicular phase of the sheep oestrous cycle Journal of Endocrinology 126 377-384

Castonguay F, Dufour JJ, Minvielle F and Estrada R (1990) Follicular dynamics and dominance in Booroola $\times$ Finnish Landrace and Booroola $\times$ Suffolk ewes heterozygous for the F gene Joumal of Reproduction and Fertility 89 193-203

Cox RI, Mattner PE and Thorburn GD (1971) Changes in ovarian secretion of oestradiol-17 $\beta$ around oestrus in sheep Joumal of Endocrinology 49 345-346 
Currie WD and Rawlings NC (1989) Prolonged infusion of morphine and naloxone in the ewe: fluctuation in responsiveness of $\mathrm{LH}$ and lack of responsiveness of FSH Journal of Reproduction and Fertility 86 359-366

Dobson H and Ward WR (1977) Alterations in plasma gonadotrophin patterns caused by sodium pentobarbitone in ewes at oestrus and in anoestrous ewes after infusion of oestradiol Jouma! of Endocrinology 75 109-118

Driancourt MA and Cahill LP (1984) Preovulatory follicular events in sheep Journal of Reproduction and Fertility 71 205-211

Driancourt MA, Gauld IK, Terqui M and Webb R (1986) Variations in patterns of follicle development in prolific breeds of sheep journal of Reproduction and Fertility 78 565-575

Driancourt MA, Philipon P, Locatelli A, Jacques E and Webb R (1988) Are differences in FSH concentrations involved in the control of ovulation rate in Romanov and Ile-de-France ewes? Journal of Reproduction and Fertility 83 509-516

Driancourt MA, Bodin L, Boomarov O, Thimonier J and Elsen JM (1990) Number of mature follicles ovulating after a challenge of human chorionic gonadotrophin in different breeds of sheep at different physiological stages Journal of Animal Science 68 719-724

Dufour J, Cahill LP and Mauleon P (1979) Short- and long-term effects of hypophysectomy and unilateral ovariectomy on ovarian follicular populations in sheep Joumal of Reproduction and Fertility 57 301-309

Fortune JE, Sirois J and Quirk SM (1988) The growth and differentiation of ovarian follicles during the bovine estrous cycle Theriogenology 29 95-110

Fortune JE, Sirois J, Turzillo AM and Lavoir M (1991) Follicle selection in domestic ruminants Journal of Reproduction and Fertility Supplement $\mathbf{4 3}$ 187-198

Ginther OJ, Kastelic JP and Knopf L (1989) Composition and characteristics of follicular waves during the bovine estrous cycle Animal Reproduction Science 20 187-200

Hunter MG, Hindle JE, McLeod BJ and McNeilly AS (1988) Treatment with bovine follicular fluid suppresses follicular development in gonadotrophinreleasing hormone treated anoestrous ewes Journal of Endocrinology 119 95-100

Hutchinson JSM and Robertson HA (1966) The growth of the follicle and corpus luteum in the ovary of sheep Research in Veterinary Science 7 17-24

Joseph IBJK, Currie WD and Rawlings NC (1991) Effects of time after ovariectomy, season and oestradiol on luteinizing hormone and follicle stimulating hormone secretion in ovariectomized ewes journal of Reproduction and Fertility 94 511-523

Knopf L, Kastelic JP, Schallenberger E and Ginther OJ (1989) Ovarian follicular dynamics in heifers: test of two-wave hypothesis by ultrasonically monitoring individual follicles Domestic Animal Endocrinology 6 111-119

McNatty KP, Gibb M, Dobson C, Ball K, Coster D, Heath D and Thurley DC (1982) Preovulatory follicular development in sheep treated with PMSG and/or prostaglandin Journal of Reproduction and Fertility 65 111-123

McNatty KP, Hudson N, Gibb M, Ball K, Fannin J, Kieboom L and Thurley DC (1984) Effects of long term treatment with $\mathrm{LH}$ on induction of cyclic ovarian activity in seasonally anoestrous ewes Journal of Endocrinology $10067-73$

McNatty KP, Henderson KM, Lun S, Heath DA, Ball K, Hudson NL, Fannin J, Gibb M, Kieboom LE and Smith $P$ (1985) Ovarian activity in Booroola $\times$ Romney ewes which have a major gene influencing their ovulation rate Joumal of Reproduction and Fertility 73 109-120

McNeilly AS, Jonassen JA and Fraser HM (1986) Suppression of follicular development after chronic LHRH immunoneutralization in the ewe Journal of Reproduction and Fertility 76 481-490

McNeilly AS, Picton HM, Campbell BK and Baird DT (1991) Gonadotrophic control of follicle growth in the ewe Journal of Reproduction and Fertility Supplement 43 177-186

McNeilly AS, Crow W, Brooks J and Evans G (1992) Luteinizing hormone pulses, follicle stimulating hormone and control of follicle selection in sheep Journal of Reproduction and Fertility Supplement 45 5-19
Martin GB, Price CA, Thiery J-C and Webb R (1988) Interactions between inhibin, oestradiol and progesterone in the control of gonadotrophin secretion in the ewe Journal of Reproduction and Fertility 82 319-328

Mattner PE and Braden AWH (1972) Secretion of oestradiol-17 $\beta$ by the ovine ovary during the luteal phase of the oestrous cycle in relation to ovulation Journal of Reproduction and Fertility 28 136-137

Medhamurthy R, Carruthers TD and Manns JG (1987) Effects of bovine follicular fluid inhibin on serum gonadotrophin concentrations in ewes during oestrus Journal of Reproduction and Fertility 81 91-98

Ortavant R, Bocquier F, Pelletier J, Ravault JP, Thimonier J and Volland-Nail P (1988) Seasonality of reproduction in sheep and its control by photoperiod Australian Journal of Biological Sciences 41 69-85

Pant HC, Hopkins CRN and Fitzpatrick RJ (1977) Concentration of oestradiol, progesterone, luteinizing hormone and follicle stimulating hormone in the jugular venous plasma of ewes during the oestrous cycle Journal of Endocrinology 73 247-255

Picton HM and McNeilly AS (1991) The effects of basal and pulsatile LH release on FSH stimulated follicle growth in ewes chronically treated with a gonadotrophin releasing-hormone agonist Journal of Endocrinology $\mathbf{1 2 8}$ 449-456

Pierson RA and Ginther OJ (1987) Reliability of diagnostic ultrasonography for identification and measurement of follicles and detecting the corpus luteum in heifers Theriogenology 28 929-936

Pierson RA and Ginther OJ (1988) Follicular populations during the estrous cycle in heifers. III. Time of selection of the ovulatory follicle Animal Reproduction Science 16 81-95

Rawlings NC, Jeffecoate IA and Rieger DL (1984) The influence of oestradiol$17 \beta$ and progesterone on peripheral serum concentrations of luteinizing hormone and follicle stimulating hormone in the ovariectomized ewe Theriogenology 22 473-488

Rawlings NC, Jeffecoate IA and Howell WE (1987) Response of purebred and crossbred ewes to intensified management Joumal of Animal Science 65 651-657

Savio JD, Keenan L, Boland MP and Roche JF (1988) Pattern of growth of dominant follicles during the oestrous cycle of heifers Journal of Reproduction and Fertility 83 663-671

Scaramuzzi RJ, Caldwell BV and Moor RM (1970) Radioimmunoassay of LH and oestrogen during the oestrous cycle of the ewe Biology of Reproduction 3 110-119

Schrick FN, Surface RA, Pritchard JY, Dailey RA, Townsend EC and Inskeep EK (1993) Ovarian structures during the oestrous cycle and early pregnancy in ewes Biology of Reproduction 49 1133-1140

Sirois J and Fortune JE (1988) Follicular dynamics during the estrous cycle in heifers monitored by realtime ultrasonography Biology of Reproduction 39 308-317

Smeaton TC and Robertson HA (1971) Studies on the growth and atresia of Graafian follicles in the ovary of the sheep Journal of Reproduction and Fertility $25243-252$

Statview (1986) Abacus Concepts Inc. Brain Power Inc., Calabsas, CA.

Webb R and Gauld IK (1985) Genetics and physiology of follicle recruitment and maturation during seasonal and lactational anoestrus. In Endocrine Causes of Seasonal and Lactational Anoestrus in Farm Animals, pp 19-28 Eds F Ellendorf and F Elsaesser. Martinus Nijhoff Publishers, The Hague

Webb R, Gauld IK and Driancourt MA (1989) Morphological and functional characteristics of large antral follicles in three breeds of sheep with different ovulation rates Journal of Reproduction and Fertility 87 243-255

Webb R, Gong JG, Law AS and Rushbridge SM (1992) Control of ovarian function in cattle Journal of Reproduction and Fertility Supplement 45 141-156 